\title{
Şanlıurfa Ekolojik Koşullarında Yetiştirilen Bazı Nohut (Cicer arietinum L.) Çeșitlerinin Verim ve Verim Unsurlarının Belirlenmesi*
}

\author{
Ömer Demirci ${ }^{1 *}$, Numan Bildirici ${ }^{2}$ \\ 1*Yüzüncü Y1l Üniversitesi, Ziraat Fakültesi, Tarla Bitkileri, Van, Türkiye (ORCID: 0000-0002-0368-567X), omer__demirci@ @otmail.com \\ ${ }^{2}$ Yüzüncü Y1l Üniversitesi Gevaş Meslek Yüksek Okulu Bitkisel ve Hayvansal Üretim Bölümü, Gevaş, Türkiye (ORCID: 0000-0003-3587-8561),
}

(İlk Geliş Tarihi 18 Haziran 2020 ve Kabul Tarihi 05 Aralık 2020)

(DOI: 10.31590/ejosat.754332)

\begin{abstract}
ATIF/REFERENCE: Demirci, Ö. \& Bildirici, N. (2020). Şanlıurfa Ekolojik Koşullarında Yetiştirilen Bazı Nohut (Cicer arietinum L.) Çeşitlerinin Verim ve Verim Unsurlarının Belirlenmesi. Avrupa Bilim ve Teknoloji Dergisi, (20), 656-662.

öz

$\mathrm{Bu}$ araştırma Türkiye'de tescili edilmiş on dört nohut çeşidi (Azkan, Gökçe, İnci, Tavas, Arda, Aksu, Çağatay, Canıtez, Diyar-95, Işık- 05, Yaşa-05, Çakır, Akça ve Hisar) ile Şanlıurfa ekolojik şartlarında verim ve verim unsurların belirlemek amacıyla 2017 yılında yapılmıştır. Deneme, Tesadüf Blokları Deneme desenine göre üç tekerrürlü olarak yürütülmüștür. Çalışmada çeşitlerin çiçeklenme süresi, fizyolojik olum, bitki boyu, ilk bakla yüksekliği, dal sayısı, bitkide bakla sayısı, baklada tane sayısı, yüz tane ağırlığı ve tane verimi parametreleri incelenmiştir. Araştırma bulgularına göre çeşitlerin çiçeklenme süresi 47.3-53.6 gün (ArdaAzkan), fizyolojik olum 72-79.3 gün (Akça-Azkan), bitki boyu 39.- $48.3 \mathrm{~cm}$ (Çağatay-Hisar), ilk bakla yüksekliği 28.8-38.8 cm (Çakır-Hisar), dal sayısı 2-3.3 adet/bitki (Tavas-Arda), bakla sayısı 6.9-13 adet/bitki (Aksu-Çakır), baklada tane sayısı 0.9-1.2 adet/bakla (Arda-Çağatay), yüz tane ağırlığı 39.8-29.5 g (Işık 05-Diyar 95) tane verimi 140.6-398.7 kg/da (Diyar 95-Akça), aralıklarında belirlenmiştir. Araştırma sonunda elde edilen veriler göre tane verimi yönünden en yüksek değere sahip olan Akça ve Yaşa 05 çeşitleri bölge için kültürü yapılması tavsiye edilebilir. Ancak daha sağlıklı karar verebilmek için ekim zamanı, bitki sıklı̆ğ ve gübrelemeye dayalı ayrıntılı bilimsel çalışmalarla desteklenmelidir.
\end{abstract}

Anahtar Kelimeler: Nohut, Çeşit, Verim, Verim özellikleri

\section{Determination of Yield and Yield Components of Some Chickpea (Cicer arietinum L.) Varieties Growed in the Şanlıurfa Ecological Conditions}

\begin{abstract}
This research registration made in Turkey fourteen chickpea varieties (Azkar, Gökçe, İnci, Tavas, Arda, Aksu, Çağatay, Canıtez, Diyar-95, Işık-05, Yaşa-05, Çakır, Akça and Hisar) with a yield of Sanliurfa ecological conditions and it was done in 2017 to determine efficiency factors. The experiment was carried out in three replications according to the Randomized Blocks Trial pattern. In the study, flowering time, physiological maturity, plant height, first pod height, number of branches, number of pods per plant, number of seeds per pod, hundred-grain weight and grain yield parameters were investigated. According to the research findings, the flowering period of the varieties is 47.3-53.6 days (Arda-Azkan), physiological maturity 72-79.3 days (Akça-Azkan), plant height 39.$48.3 \mathrm{~cm}$ (Çağatay-Hisar), first pod height 28.8-38.8 cm (Çakır -Hisar), the number of branches 2-3.3 pieces/plant (Tavas-Arda), the number of pods 6.9-13 pieces / plant (Aksu-Çakır), the number of seeds per pod is 0.9-1.2 pieces/pod (Arda-Çağatay), hundred grain weight the grain yield of 39.8-29.5 g (Işık 05-Diyar 95) was determined in the range of 140.6-398.7 kg/da (Diyar 95-Akça). According to the data obtained at the end of the research, it can be recommended to culture the Akça and Yaşa 05 varieties, which have the highest value in terms of grain yield, for the region. However, in order to make a healthier decision, it should be supported with detailed scientific studies based on planting time, plant density and fertilization.
\end{abstract}

Key Words: Chickpea, Variety, Yield, Yield components

*Sorumlu Yazar: omer_demirci@hotmail.com 


\section{Giriş}

Türkiye'de tarla bitkileri üretimi yapılan toplam alanın yaklaşık \%74'ünü oluşturan tahıllar birinci, \% 8.3'ünü oluşturan yemeklik tane baklagiller ise ikinci sırada yer almaktadır(TÜİK 2018). İnsan beslenmesindeki önemi; cins, tür, çeşit ve yetiştirme yöntemlerine göre değişmekle birlikte, kuru taneleri \% 18-36 protein içerir. Bu oran, yazlık yetiştirilenlerde, kışlık ekilenlerden daha yüksek olmakta (Tahıl (\% 9-12)'ların 2-3 kat1); ayrica A, B ve D vitaminlerince de zengin bir yap1 göstermektedirler (Ulukan, 2012). Son yıllarda hareketliliği azalan insanların beslenmesinde yağ ile birlikte bulunmadığı için diyet yemeği olarak hayvansal proteinlere karşı tercih edilmekte; ayrıca hayvanlarca tüketildiklerinde, proteinleri çok daha iyi değerlendirilmektedir. Proteinleri insan beslenmesi için amino asitlerce dengeli olup içlerinden olmazsa olmaz olan "alınması zorunlu amino asitler" bakımından (Örneğin "isoleucine, leucine, phenylalanine v.b.") zengindir. Nohut iyi bir protein ve karbonhidrat kaynağı olması, bazı mineralleri (kalsiyum, magnezyum, çinko, potasyum, demir, fosfor) ve tiamin ile niasin gibi vitaminleri içermesi bakımından besin olarak büyük bir öneme sahiptir (Kaur ve ark., 2005). Ayrica nohut insan ve hayvanlar için çok önemli bir gıda kaynağı olmasının yanında, özellikle düşük yağışlı ya da yağış almayan bölgelerde toprak verimliliğinin sürdürülmesinde önemli rol oynamaktadır (Saxena, 1990). Nohudun tane verimini etkileyen önemli faktörlerden biri de ekim zamanıdır. Optimal olarak ekim zamanından sapma iklim ve çevre koşullarındaki değişim nedeniyle, bitki gelişmesini ve büyümesini olumsuz bir şekilde etkilemektedir. Kıyı bölgeleri dışında karasal iklime sahip iç bölgelerde ekim yazlık olarak Şubat ayından Mayıs ayına kadar değişen zamanlarda yapılmaktadır. Erken ekimde toprakta fazla nem bulunduğundan, aşırı vejetatif büyüme olmakta ve toprağın suyla fazla doyması sonucu hastalıklar yaygınlaşmakta ve tane verimi düşmektedir. Buna karşılık geç ekimde artan sıcaklıklar nedeniyle sınırlı toprak nemi çimlenmeyi olumsuz yönde etkilemekte ve optimum bitki sıklığından daha az bitki çıkış yapmakta, vejetatif ve generatif dönemlerin kısalması ile verim azalmaktadır. Doğu Anadolu gibi kışı sert ve uzun geçen ve genellikle yıllık yağışı düşük bölgelerde ekimin geç yapılması, toprakta nemin azalması ve generatif dönemin yüksek sıcaklıklara rastlaması nedeniyle verimi düşürmektedir. Yetiştiricilerin nohut ekimini Mayıs ayına kaydırmalarının nedeni antraknoz hastalığından kaçınmaktır. Böyle durumlarda bitki yeterli vejetatif büyüme yapmadan generatif devreye girmekte ve dolayısıyla verimde önemli düşmeler meydana gelmektedir (Açıkgöz, 1987). Drenajı iyi olan, verimli, kumlu, organik madde bakımından zengin ve $\mathrm{pH}$ 's1 5.5-8.6 arasında değişen topraklar nohut yetiştiriciliği açısından oldukça uygundur. Ülkemizde bazı kıyı bölgelerimiz hariç, özellikle Orta Anadolu'da sulanmadan kuru koşullarda yetiştirilmektedir ve verim doğrudan ekolojik koşulların etkisi altındadır (Babaoğlu, 2003). Toprak neminin azalması ve yetiştirme süresinin kısalması gibi nedenlerden dolayı bilhassa geç ekimlerde verim \% 26-68 oranında düşmektedir (Üstün, 1994). Yemeklik tane baklagillerin taneleri ve sapları hayvan beslenmesinde kullanılmaktadır. Hayvancılıkta kaba yem ihtiyacı işletme giderlerinin yaklaşık \% 70'ni oluşturmaktadır. Bir ton tahıl sapında $70.5 \mathrm{~kg}$ protein, 1 ton baklagil sapında $137.4 \mathrm{~kg}$ protein bulunmaktadır (Azkan, 1999). Yemeklik baklagiller içerisinde dünyada en fazla ekimi yapılan nohut (Cicer arietinum L.) hem Rhizobium ciceri bakterileri sayesinde havanın serbest azotunu köklerinde bulunan nodüller yardımıyla toprağa bağlayarak toprağın azotça zenginleşmesini sağlamakta ve böylece sürdürülebilir tarım yapılmasına yardımcı olmakta, hem de nadas alanlarının daraltılmasında ekim nöbeti bitkisi olarak tarımsal üretim sistemlerinin çeşitlendirilmesini sağlamaktadır (Gan ve ark., 2005). Türkiye'de 1980'li yıllarda uygulamaya konulan Nadas Alanlarının Daraltılması projesi çalışmalarıyla özelikle nohut ve mercimeğin tahıllarla ekim nöbetine giren ve en fazla gelir sağlayan bitkiler olduğunun saptanmış olması sonucu, daraltılan nadas alanlarının \%65-70'lik kısmını nohut ve mercimek ekimi kaplamıştır (Yeşilgün 2006). Nohut bitkisi topraktaki Rhizobium ciceri bakterisi vasitasıyla dekara $8 \mathrm{~kg}$ saf azot bağlayabilmektedir. Ülkemizde 2018 yılı verilerine göre 8.879.229 dekar alanda baklagiller (nohut, mercimek, fasulye, bakla, börülce, bezelye) yetiştirilmektedir. Ekiliş alanı bakımından baklagiller, tahıllardan sonra en önemli yeri tutmaktadır. Bu çalışmada 2018 yılı verilerine göre, yemeklik tane baklagil cinslerinin içerisinde yaklaşık 5.144.159 dekar ekim alanı ile nohut ilk sirayı almakta nohudu 2.772.277 dekar ile mercimek, 848.045 dekar ile fasulye, 47.722 dekar ile bakla, 13.553 dekar ile börülce ve 9.065 dekar ile bezelye takip etmektedir. Şanlıurfa ilinin 2018 verilerine göre nohut ekim alanı 15.671 dekardır. Üretim 1.956 ton, verim ise $125 \mathrm{~kg} / \mathrm{da}$ olarak gerçekleşmiştir (Anonim, 2018). Farklı on dört nohut çeşitlerinin Şanlıurfa ekolojik koşullarında yetiştirilen bazı nohut çeşitlerinin verim ve verim unsurlarının belirlenmesi ve bölgedeki çiftçilere katkı sağlamak amacıyla çalışılmıştır.

\section{Materyal ve Metot}

Araştırma materyali; Türkiye'de tescili yapılmış on dört farklı nohut çeşidi (Azkan, Gökçe, İnci, Tavas, Arda, Aksu, Çağatay, Canıtez, Diyar-95, Işık- 05, Yaşa-05, Çakır, Akça ve Hisar) Şanlıurfa Güneydoğu Tarımsal Araştırma Enstitüsü ve Eskişehir Geçit Kuşağı Tarımsal Araştırma Enstitüsünden temin edilmiştir. Şanlıurfa ekolojik koşullarında yetiştirilen bazı nohut çeşitlerinin verim ve verim unsurlarının belirlenmesi amacıyla yaptığımız bu çalışma 2017 yılında Şanlıurfa ilinin Hilvan ilçesinde yapılmıştır. Çalışma alanına ait iklim verileri Meteoroloji Genel Müdürlügüünden alınmıştır. Çizelge 2.1'de görüldüğü gibi uzun yıllar (2000-2016) ait ve 2017 y1lına ait verilerdeki ortalama sıcaklık bakımından en soğuk ay Şubat, en sıcak ay ise Haziran'dır. Uzun yıllar ortalaması (2000-2016) göre ortalama nispi nem değeri en yüksek Şubat, en düşük ise Haziran ayı, 2017 yılına ait ortalama nispi nem değeri en yükseği ise Mart, en düşüğü Haziran ayıdır. Uzun yıllar ortalaması (2000-2016) göre ortalama yağış değeri en yüksek olan ay Şubat, en düşük ay ise Haziran, 2017 yılına ait ortalama yağış değeri en yüksek ay Nisan, en düşük ay ise Haziran'dır. 
Çizelge 2.1. Şanlıurfa ilinin uzun yıllara (2000-2016) ve 2017 yllına dair ortalama sıcakllk, nispi nem ve yağış değerleri

\begin{tabular}{lcccccc}
\hline \multirow{2}{*}{ Aylar } & \multicolumn{2}{c}{${\text { Ort. Sicaklık }\left({ }^{\circ} \mathbf{C}\right)}^{2}$ Ort. Nispi Nem } & \multicolumn{2}{c}{ Yağış $(\mathbf{m m})$} \\
\cline { 2 - 7 } & UYO & $\mathbf{2 0 1 7}$ & UYO & $\mathbf{2 0 1 7}$ & UYO & $\mathbf{2 0 1 7}$ \\
\hline Şubat & 7.83 & 7.5 & 67.1 & 45.6 & 67.72 & 1.8 \\
Mart & 12.81 & 12.7 & 57.78 & 56.8 & 44.71 & 55.2 \\
Nisan & 17.2 & 16.5 & 53.81 & 50.9 & 40.78 & 79.3 \\
Mayls & 22.81 & 22.5 & 41.72 & 39.3 & 20.02 & 7.2 \\
Haziran & 27.44 & 29.6 & 32.94 & 27.8 & 5.75 & 0 \\
Ortalama & 17.61 & 17.76 & 50.67 & 44.08 & 35.79 & 28.7 \\
\hline UYO:
\end{tabular}

UYO: Uzun Ylllar Ortalamast

Arazi toprağın $0-30 \mathrm{~cm}$ derinliğinden alınan örneklerin analizi Harran Üniversitesi Ziraat Fakültesi Toprak Bölümü laboratuarında analiz edilmiştir. Çizelge $2.2^{\prime}$ 'deki sonuçlara bakıldığında; toprak hafif alkali özellikte, kireç oranı ile orta dereceli, organik madde yönüyle orta dereceli, EC değeri bakımından $4 \mathrm{ds} \mathrm{m}^{-1}$ az olduğu için asidik bir toprak, kum, kil ve silt oranlarını tekstür üçgeninde bakıldığında killi bir bünye sahip olduğu anlaşılmaktadır.

Çizelge 2.2. Deneme alanı toprağının $(0-30 \mathrm{~cm})$ bazı fiziksel ve kimyasal analiz sonuçları

\begin{tabular}{lcl}
\hline Özellik & Sonuç & Değerlendirme \\
\hline Organik madde(\%) & 2.7 & Orta \\
Kirę̧(\%) & 5.07 & Orta \\
EC $(\%)$ & 1.12 & Asidik \\
Kum(\%) & 1.92 & Düşük \\
Kil (\%) & 67.97 & Yüksek \\
Silt & 30.16 & Düşük \\
\hline
\end{tabular}

Çalışma 2017 yılında üç tekerrürlü olarak tesadüf blokları deneme desenine göre kurulmuş olup, toplamda 42 parselden oluşmuştur. Tüm parsellerde ekim alanı 5.0 x $1.5=7.5 \mathrm{~m}^{2}$ dir. Her parsele beşer sıra olarak ekim yapılmıştır. Deneme parsellerinde sira arasi mesafe $30 \mathrm{~cm}$, parseller arasi mesafe $1 \mathrm{~m}$ ve bloklar arası mesafe ise $2 \mathrm{~m}$ şeklinde olmuştur. $1 \mathrm{~m}^{2}$ alana 33 adet tohum atılmıştır. Tohum ekiminden önce dekara $3 \mathrm{~kg}$ saf azot, $8 \mathrm{~kg} \mathrm{P}_{2} \mathrm{O}_{5}$ denk gelecek şekilde DAP gübresi verilmiştir. Hasatta her parsel başından $0.50 \mathrm{~m}$ ve parsel yanlarından birer sırada bulan bitkiler gözlem dışında bırakılmıştır. İnceleme ve hesaplamalar kenar tesiri dışında kalan $4 \mathrm{~m}$ x $0.90 \mathrm{~m}=3.6$ $\mathrm{m}^{2}$ 'lik alanından yapılmıştır (Şehirali, 1988). Çalışma alnında ön hazırlık olarak traktörle derin sürüm işlemi yapıldıktan sonra kültivatör aracılığıyla tohum yatağı hazırlanmıştır. Ekim markörü kullanılarak 26 Şubat 2017 tarihinde yapılmıştır. Deneme alanı yabanc1 ot mücadelesi $3 \mathrm{kez}$ mekanik olarak yapılmıştır. Hasat işlemi 15-28 Haziran 2017 tarihleri arasında elle yapılmıştır. Hasat edilen bitkilerde ölçüm, sayım ve harmanlama işlemleri yapılmış ve ortalamaları alınmıştır. Araştırmada kullanılan nohut çeşitlerinin verim ve verim öğeleri açısından aralarındaki farklılı̆ı̆ı belirlenmesinde tesadüf blokları deneme deseni ve Duncan varyans analizi metodu programı kullanılmıştır. Ortalama değerler arasında oluşan grupların belirlenmesinde ise LSD (\%5) Çoklu Karşılaştırma Testi'nden (Düzgüneş ve ark., 1987) ve Costat paket programından faydalanmışıtır.

\section{Bulgular ve Tartışma}

\section{1. Çiçeklenme Süresi}

Araştırmada elde edilen nohut çeşitlerine ait çiçeklenme süresi özellikleri Tablo 1'de verilmiştir. Nohut çeşitlerinin çiçeklenme süresi istatistiki analiz sonuçları $\% 1$ düzeyinde önemli olarak belirlenmiş̧ir. Tablo l'de görüldüğü gibi çiçeklenme süresi 47.3-53.6 gün arasında değişmekte olup; en düşük değer 47.3 gün ile Arda, en yüksek değer ise 53.6 gün ile Azkan çeşidinde bulunmuştur. Yapılmış farklı çalışmalarda çiçeklenme süresi ise; 76.2-84.6 gün Biçer ve Anlarsal (2004), 44 gün Beysarı (2012), 55 gün, Erdemci (2012), 57.5- 65.5 gün Uzun ve ark. (2012), 57-62.3 gün Karakan Kaya (2014), 56.5 gün Bayrak ve ark.(2015) olarak tespit etmişlerdir. Yaptığımız çalışmada çiçeklenme süresi önceki çalışmaların bazıları ile benzerlik gösterirken bazıları ile farklılık göstermemektedir. Bu farklılığın nedenleri ise kullanılan genotipler ve çevre koşullarında etkilendiği düşünülmektedir.

\subsection{Fizyolojik Olum}

Araştırmada elde edilen nohut çeşitlerine ait fizyolojik olum özellikleri Tablo 1'de verilmiştir. Nohut çeşitlerinin fizyolojik olum istatistiki analiz sonuçları \% 1 düzeyinde önemli olarak belirlenmiştir. Tablo 1'de görüldüğü gibi fizyolojik olum 
69.33-79.33 gün arasında değișmekte olup; en düşük değer 69.3 gün ile Arda, en yüksek değer ise 79.33 gün Azkan çeşidinde bulunmuştur. Yapılmış farklı araştırmalarda fizyolojik olum ise; 79 gün Beysarı (2012), 70.3-72.3 gün Karakan Kaya (2014), 78.5-89 gün Güngör ve Dumlupınar (2018), 71.7-84.7 gün Ercan ve ark. (2019) olarak tespit etmişlerdir. Yaptığımız çalışmada fizyolojik olum önceki çalışmaların bazıları ile benzerlik gösterirken bazıları ile farklılık göstermemektedir. Bu farklılığın nedenleri ise kullanılan genotipler ve çevre koşullarında etkilendiği düşünülmektedir.

\subsection{Bitki Boyu}

Araştırmada elde edilen nohut çeşitlerine ait bitki boyu özellikleri Tablo 1'de verilmiştir. Nohut çeşitlerinin bitki boyu istatistiki analiz sonuçları \% 1 düzeyinde önemli olarak belirlenmiştir. Tablo 1'de görüldüğü gibi bitki boyu $39-48.3 \mathrm{~cm}$ arasında değişmekte olup; en düşük değer $39 \mathrm{~cm}$ ile Çağatay, en yüksek değer $48.3 \mathrm{~cm}$ ile Hisar çeşidinde bulunmuştur. Yapılmış farklı çalışmalarda bitki boyu ise; 33.5-51.4 cm Akman (1993), $34-49.7 \mathrm{~cm}$ Türk ve Koç (2003), $32.8 \mathrm{~cm} \mathrm{Bakoğlu} \mathrm{ve}$ A yçiçek (2005), 42.6-49.7 cm Babagil (2011),34.-40.2 cm Uzun ve ark. (2012), $43.2 \mathrm{~cm}$ Bayrak ve ark.(2015), 38.2-41.9 cm Yalçın ve ark. (2018), 30.5-47.4 cm Ercan ve ark. (2019) olarak tespit etmişlerdir. Yaptığımız çalışmada bitki boyu önceki çalışmaların bazıları ile benzerlik gösterirken bazıları ile farklılık göstermemektedir. Farklılık sebepleri ise kullanılan genotiplerin ve çevresel koşullardan etkilendiği düşünülmektedir. Bitki boyu kısa olan çeşitlerin makineli hasatta önemli oranda tane kayıplarına yol açabileceğinden uzun boylu çeşitlerin tercih edilmesi büyük önem arz eder (Bakoğlu ve Memiş, 2002). Bitki boyunun uzun olması makineli hasatta tane kaybının aza inmesine imkan sağlamaktadır.

Tablo 1. Farkl nohut çeşitlerine ait çiçeklenme süresi (ÇS), fizyolojik olum(FO), bitki boyu (BB), ilk bakla yüksekliği(İBY), bitkide dal sayısı (BDS), bitkide bakla sayısı (BBS), baklada tane sayısı (BTS), bitkide tane sayısı (BITS), yüz tane a $\breve{g} ı r l ı \breve{g l}(Y T A)$,tane verimi $(T V)$

\begin{tabular}{|c|c|c|c|c|c|c|c|c|c|}
\hline Çeşit & $\begin{array}{c}\text { ÇS } \\
\text { (gün) }\end{array}$ & $\begin{array}{c}\text { FO } \\
\text { (gün) }\end{array}$ & $\begin{array}{c}\text { BB } \\
(\mathrm{cm})\end{array}$ & İBY $\quad(\mathrm{cm})$ & $\begin{array}{c}\text { BDS } \\
\text { (adet) }\end{array}$ & BBS (adet) & $\begin{array}{c}\text { BTS } \\
\text { (adet) }\end{array}$ & $\begin{array}{c}\text { YTA } \\
\text { (g) }\end{array}$ & $\begin{array}{c}\text { TV } \\
(\mathbf{k g})\end{array}$ \\
\hline Azkan & $53.6 \mathrm{a}$ & $79.3 \mathrm{a}$ & $40.9 \mathrm{bc}$ & $34.2 \mathrm{ad}$ & 22.3 & $7.73 \mathrm{~cd}$ & 1 & $34.2 \mathrm{abc}$ & $198 \mathrm{e}$ \\
\hline Gökçe & $50 \mathrm{bcd}$ & $74.6 \mathrm{de}$ & $40.6 \mathrm{bc}$ & $30.1 \mathrm{de}$ & 22.3 & $10.1 \mathrm{ac}$ & 1 & $38.6 \mathrm{a}$ & $334.6 \mathrm{bc}$ \\
\hline İnci & $52.6 \mathrm{a}$ & $76.3 \mathrm{~b}$ & $41.1 \mathrm{bc}$ & $37.8 \mathrm{ab}$ & 22.6 & $8.3 \mathrm{~cd}$ & 0.9 & 30. c & $288 \mathrm{~cd}$ \\
\hline Tavas & $49.3 \mathrm{de}$ & $72.6 \mathrm{f}$ & $39.8 \mathrm{bc}$ & 32.2 cde & 22 & $9.3 \mathrm{bd}$ & 1 & $35.3 \mathrm{abc}$ & $356 \mathrm{~b}$ \\
\hline Arda & $47.3 \mathrm{f}$ & $69.3 \mathrm{~g}$ & $42.6 \mathrm{bc}$ & $37 \mathrm{abc}$ & 33.3 & $8 \mathrm{~cd}$ & 0.9 & $34.9 \mathrm{abc}$ & $270.6 \mathrm{~d}$ \\
\hline Aksu & $49.6 \mathrm{~cd}$ & $74 \mathrm{e}$ & $42.3 \mathrm{bc}$ & $34.1 \mathrm{ad}$ & 22.6 & $6.9 \mathrm{~d}$ & 1.1 & $35.2 \mathrm{abc}$ & $337.6 \mathrm{bc}$ \\
\hline Çağatay & $50.6 \mathrm{bc}$ & $74.6 \mathrm{de}$ & $39 \mathrm{c}$ & $32.5 \mathrm{cde}$ & 22.6 & $9.9 \mathrm{ad}$ & 1.2 & $38.9 \mathrm{a}$ & $318 \mathrm{c}$ \\
\hline Canitez & $51 \mathrm{~b}$ & $75.3 \mathrm{bcd}$ & $40.5 \mathrm{bc}$ & $34.2 \mathrm{ad}$ & 22.6 & $10 \mathrm{ac}$ & 1.1 & $38.7 \mathrm{a}$ & $386.6 \mathrm{a}$ \\
\hline Diyar-95 & $48.3 \mathrm{ef}$ & $70.3 \mathrm{~g}$ & $40.3 \mathrm{bc}$ & 33.2 be & 33 & $8.2 \mathrm{~cd}$ & 0.9 & $29.5 \mathrm{c}$ & $140.6 \mathrm{f}$ \\
\hline Işık-05 & $51 \mathrm{~b}$ & $74 \mathrm{e}$ & $43.2 \mathrm{bc}$ & $35.7 \mathrm{abc}$ & 33 & $10.4 \mathrm{ac}$ & 0.9 & $39.8 \mathrm{a}$ & $338 \mathrm{bc}$ \\
\hline Yaşa-05 & $50.3 \mathrm{bcd}$ & $74.3 \mathrm{de}$ & $43.5 \mathrm{~b}$ & $34.8 \mathrm{ad}$ & 22.6 & $9.8 \mathrm{bd}$ & 1.1 & $38.8 \mathrm{a}$ & 389 a \\
\hline Çakır & $52.6 \mathrm{a}$ & $76 \mathrm{bc}$ & $39.4 \mathrm{bc}$ & $28.8 \mathrm{e}$ & 33 & 13. a & 1 & $36.9 \mathrm{ab}$ & $379.3 \mathrm{ab}$ \\
\hline Akça & $49.3 \mathrm{de}$ & $72 \mathrm{f}$ & $42.9 \mathrm{bc}$ & $34 \mathrm{ad}$ & 33 & $11.6 \mathrm{ab}$ & 1.1 & $39 \mathrm{a}$ & $398.7 \mathrm{a}$ \\
\hline Hisar & $51 \mathrm{~b}$ & $75 \mathrm{cde}$ & $48.3 \mathrm{a}$ & $38.8 \mathrm{a}$ & 33 & $7.3 \mathrm{~cd}$ & 1.1 & $32.3 \mathrm{bc}$ & $266 \mathrm{~d}$ \\
\hline Ortalama & 50.4 & 74.1 & 41.7 & 34.1 & 26.09 & 9.3 & 1 & 35.8 & 314.3 \\
\hline
\end{tabular}

* Aynı harfler ile gösterilen ortalamalar arasındaki farklar önemli değildir. 


\section{4. İlk Bakla Yüksekliği}

Araştırmada elde edilen nohut çeşitlerine ait ilk bakla yüksekliği özellikleri Tablo 1'de verilmiştir. Nohut çeşitlerinin ilk bakla yüksekliği istatistiki analiz sonuçları \% 1 düzeyinde önemli olarak belirlenmiştir. Tablo 1'de görüldüğü gibi ilk bakla yüksekliği 28.8-38.8 cm arasında değişmekte olup; en düşük değer $28.8 \mathrm{~cm}$ ile Çakır, en yüksek değer $38.8 \mathrm{~cm}$ ile Hisar çeşidinde bulunmuştur. Yapılmış farklı çalışmalarda ilk bakla yüksekliği ise; 10.7-14.4 cm Türk ve Koç (2003), 16 cm Bakoğlu ve Ayçiçek (2005), 24.9 cm Erdin ve Kulaz (2014), 24.4-35.1 cm Karakan Kaya (2014), 19.1-25.3 cm Dinç (2014), $29.5 \mathrm{~cm}$ Bayrak ve ark.(2015) olarak tespit etmişlerdir. Yaptığımız çalışmada bitki boyu önceki çalışmaların bazıları ile benzerlik gösterirken bazıları ile farklılık göstermektedir. $\mathrm{Bu}$ farklılığın kullanılan genotipler ve çevre koşullarından kaynaklandığı düşünülmektedir. Tarafından makineli hasat için ilk meyve yüksekliğinin 26-30 cm olması gerektiği bildirilmiştir Zeren ve ark. (1991). Çeşitlerinin ilk bakla yüksekliklerinin fazla olması makineli hasatta tane kaybının en aza inmesine imkan sağlamaktadır.

\subsection{Bitkide Dal Sayısı}

Araştırmada elde edilen nohut çeşitlerine ait bitkide dal sayısı özellikleri Tablo 1'de verilmiştir. Nohut çeşitlerinin bitkide dal sayısı açısından çeşitler arasındaki farkın önemli olmadığı görülmüştür. Yapılan LSD testi sonucuna göre bitkide dal sayısı ortalamaları arasındaki fark önemsiz çıktığı için gruplandırılmanın oluşmadığı görülmüştür. Tablo 1'de görüldüğü gibi bitkide dal sayısı 2-3.3 adet/bitki arasında değişmekte olup; en düşük değer 2 adet/bitki ile Tavas, en yüksek değer 3.3 adet/bitki ile Arda çeşidinde bulunmuştur. Yapılmış farklı çalışmalarda bitkide dal sayısı ise; 2.4-3.8 adet/bitki Akman (1993), 2.5-3.2 adet/bitki Kaçar ve ark. (2005), 2.6-3.3 adet/bitki Yiğitoğlu (2006), 2.8-3.3 adet/bitki Babagil (2011), 2.5 adet/bitki Beysarı (2012), 2.4 adet/bitki Erdemci (2012), 3.3 adet/bitki Dinç (2014), 1.7-2.7 adet/bitki Ercan ve ark.(2019) olarak tespit etmişlerdir. Yaptığımız çalışmada bitkide dal sayısı önceki çalışmalarla benzerlik gösterirken bazıları ile farklılıklar göstermektedir. Farklılık sebepleri ise kullanılan genotiplerin ve çevresel koşullardan etkilendiği düşünülmektedir.

\subsection{Bitkide Bakla Sayısı}

Araştırmada elde edilen nohut çeşitlerine ait bitkide bakla sayısı özellikleri Tablo 1'de verilmiştir. Nohut çeşitlerinin bitkide bakla sayısı istatistiki analiz sonuçları \% 1 düzeyinde önemli olarak belirlenmiştir. Tablo 1'de görüldüğü gibi çeşitlerin bitkide bakla sayısı 6.9-13 adet/bitki arasında değişmekte olup; en düşük değer 6.9 adet/bitki ile Aksu, en yüksek değer 13 adet/bitki ile Çakır çeşidinde bulunmuştur. Yapılmış farklı çalışmalarda bitkide bakla sayısı ise; 9.5-16.2 adet/bitki Akman (1993), 6.5-18.4 adet/bitki Çiftçi ve ark. (2004), 12.4 adet/bitki Bakoğlu ve Ayçiçek (2005), 7.5 adet/bitki Vural ve Karasu (2007), 5.5-8.3 adet/bitki Dinç (2014) olarak tespit etmişlerdir. Yaptığımız çalışmada bitkide bakla sayısı önceki çalışmalar ile benzerlik göstermiştir. Farklılık sebepleri ise kullanılan genotiplerin ve çevresel koşullardan etkilendiği düşünülmektedir. Özellikle nohutta dallanma ve bakla bağlama döneminde yapılan sulamanın verimde ciddi artışlara neden olduğu bildirilmektedir (Yağmur ve Engin 2005).

\subsection{Baklada Tane Sayısı}

Araştırmada elde edilen nohut çeşitlerine ait baklada tane sayısı özellikleri tablo 1'de verilmiştir. Nohut çeşitlerinin baklada tane sayısı açısından çeşitler arasındaki farkın önemli olmadığı görülmüştür. Yapılan LSD testi sonucuna göre baklada tane sayısı ortalamaları arasındaki fark önemsiz çıktığı için gruplandırılmanın oluşmadığı görülmüştür. Tablo 1'de görüldüğü gibi bitkide tane sayısı $0.9-1.2$ adet/bakla arasında değişmekte olup; en düşük değer 0.9 adet/bakla ile Diyar-95, en yüksek değer 1.2 adet/bakla ile Çağatay çeşidinde bulunmuştur. Yapılmış farklı çalışmalarda bitkide dal sayısı ise; 1-1.2 adet/bakla Karasu (1993), 1 adet/bakla Beysarı (2012), 1 adet/bakla Erdemci (2012), 1.01-1.03 adet/bakla Ceran (2014), 0.8-1 adet/bakla Patan (2014) 0.9-1.07 adet/bakla Karakan Kaya (2014), 0.93-0.97 adet/bakla Ercan ve ark.(2019) olarak tespit etmişlerdir. Yaptığımız çalışmada baklada tane sayısı önceki çalışmalarla benzerlik göstermemektedir. Baklada tane sayısı bitkide bakla sayısıyla direk ilişkilidir. Özellikle nohutta dallanma ve bakla bağlama döneminde yapılan sulamanın verimde ciddi artışlara neden olduğu bildirilmektedir (Yağmur ve Engin 2005).

\subsection{Yüz Tane Ağırlığı}

Araştırmada elde edilen nohut çeşitlerine ait yüz tane ağırlığı özellikleri tablo 1'de verilmiştir Nohut çeşitlerinin yüz tane ağırlığı istatistiki analiz sonuçları \% 1 düzeyinde önemli olarak belirlenmiştir. Tablo 1'de görüldüğü gibi çeşitlerin yüz tane ağırlığı 29.5-39.8 g arasında değişmekte olup; en düşük değer 29.5 g ile Diyar-95, en yüksek değer 39.8 g ile Işık-05 çeşidinde bulunmuştur. Yapılmış farklı çalışmalarda yüz tane

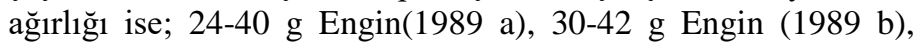
26.7-37.5 g Anlarsal ve ark. (1999) , 25.7-36.4 g Mart ve Anlarsal (2001), 33.8-46.7 g Türk ve Koç (2003), farklı sıra arası üzerine yaptıkları çalışmada 47.3-49.9 g Bildirici ve ark. (2007a), 39.3 g Öztaş ve ark. (2007), 37.6-51.5 g Karaköy (2008), 29.7-38.7 g Ercan ve ark. (2019) tespit etmişlerdir. Yaptığımız çalışmada yüz tane ağırlığı önceki çalışmaların bazıları ile benzerlik gösterirken bazıları ile farklılık göstermemektedir. Farklılık sebepleri ise kullanılan genotiplerin ve çevresel koşullardan etkilendiği düşünülmektedir.

\subsection{Tane Verimi}

Araştırmada elde edilen nohut çeşitlerine ait tane verimi özellikleri tablo 1'de verilmiştir Nohut çeşitlerinin tane verimi istatistiki analiz sonuçları \% 1 düzeyinde önemli olarak belirlenmiştir. Tablo 1'de görüldüğü gibi çeşitlerin tane verimi 140.6-398.7 kg arasında değişmekte olup; en düşük değer 140.6 kg/da ile Diyar-95, en yüksek değer 398.7 kg/da ile Akça çeşidinde bulunmuştur. Yapılmış farklı çalışmalarda tane verimi ise; $121.5-166.6 \mathrm{~kg} / \mathrm{da}$ Biçer ve Anlarsal (2003), 177.5-362.4 $\mathrm{kg} / \mathrm{da}$ Kaçar ve ark.(2005) 221-374 kg/da Bildirici ve ark. (2007b), farklı sıra arası üzerine yaptıkları çalışmada 198.4-278 $\mathrm{kg} / \mathrm{da}$ Bildirici ve ark. (2007a), 141.7-277.4 kg/da Doğan (2014), 168.5-302.2 kg/da Erdemci ve ark.(2019) tespit etmişlerdir. Tane verimindeki artışların ortaya çıkmasında sulama ve yeterli gübre uygulamalarının etkisinin önemli olduğu belirtilmiştir (Bildirici ve ark., 2007b). Özellikle nohutta dallanma ve bakla bağlama döneminde yapılan sulamanın verimde ciddi artışlara neden olduğu bildirilmektedir (Yağmur ve Engin 2005). 


\section{Sonuç}

Denemede kullanılan çeşitler üzerinde yapılan çalışmalar sonucunda bazı çeşitlerin bölge ekolojisine uygunluğu açısından öne çıktığ 1 görülmüştür. Bu çeşitlerden bitki boyu bakımından en yüksek değer Hisar $(48.3 \mathrm{~cm})$ ve Yaşa-05 $(43.5 \mathrm{~cm})$ çeşitlerinde, en düşük değer ise Çağatay $(39 \mathrm{~cm})$ çeşidinde gözlemlenmiştir. Bakla sayısı bakımından en yüksek ortalama değerler ise Çakır (13 adet) ve Akça (11.6 adet) çeşitlerinden, en düşük ise Aksu (6.9 adet) çeşidinden elde edilmiştir. En yüksek yüz tane ağırlığı Işık-05 (39.8 g) ve $\operatorname{Akça(39~g)~çeşidinde~tespit~}$ edilirken en düşük değer ise Diyar-95 (29.5 g) çeşidinde tespit edilmiştir.

Dekara tane verimi olarak en yüksek verim değeri $398.7 \mathrm{~kg} / \mathrm{da}$ ile Akça çeşidinden en az verim ise $140.6 \mathrm{~kg} / \mathrm{da}$ ile Diyar-95 çeşidinden elde edilmiştir. Çalışmanın kuru koşullarda yürütülmesi ve vejetasyon döneminde düşen yağışın miktarının düşük olması gibi sebeplerden dolayı bazı çeşitlerin dekara tane verimleri ülkemiz ortalamasının altında oluşmuştur. Bu nedenle imkânlar dâhilinde nohudun suya en çok ihtiyaç duyduğu çiçeklenme ve bakla bağlama döneminde yapılacak olan sulamanın verimi artıracağı düşünülmektedir.

Bölgede nohut yetiştiriciliğinin daha iyi duruma getirebilmek için, bu çalışmanın en az bir yıl süreyle tekrarlanması ve bölge için öne çıkan çeşitlerle (Akça ve Yaşa 05) ekim zamanı, bitki sıklığı ve gübreleme gibi bilimsel çalışmaların da yapılması gerekmektedir.

\section{Teşekkür}

Çalışmanın her safhasında yakın ilgi ve önerileri ile beni yönlendiren danışman hocam Sayın Dr. Öğr. Üyesi Numan BİLDİRİCI'ye, tohumları temininde her türlü yardımı sağlayan Güneydoğu Tarımsal Araştırma Enstitüsü Yüksek Ziraat Mühendisi Sayın Mahmut GAYBERLI'ye, istatistiki analizlerde bana yardımını esirgemeyen Ankara Üniversitesi Ziraat Fakültesi Tarla Bitkileri Anabilim Dalı Öğretim Üyesi Prof. Dr. Melahat AVCI'ya, çalışma sırasında bana maddi ve manevi desteğini esirgemeyen dayım Dr. İbrahim Halil ADAK'a özellikle her türlü yardım ve desteklerinden dolayı çok değerli sevgili aileme teşekkürlerimi sunarım.

\section{Kaynakça}

Açıkgöz, N., 1987. Nohut Tarımı, T.C. Tarım Orman ve Köy İşleri Bakanlığı, Ege Bölge Zirai Araştırma Enstitüsü Müdürlüğü Yayınları, No: 76:.21.

Akman, B. 1993. Bursa Ekolojik Koşullarına Uyan Nohut (Cicer arietinum L.) Hatlarının Belirlenmesi Üzerine Bir Araştırma, Yüksek Lisans Tezi, Uludağ Üniversitesi, Fen Bilimleri Enstitüsü

Anlarsal, A.E., C. Yücel ve D. Özveren. 1999. Çukurova Koşullarında BazıNohut (Cicer arietinum L.) Hatlarının Verim ve Verimle İlgili ÖzelliklerininSaptanması Üzerine Bir Araştırma. Türkiye 3. TarlaBitkileri Kongresi, 15-18 Kasım, Cilt III, Çayır Mera Yem Bitkileri ve Yemeklik Tane Baklagiller, s. 342-347

Anonim, 2016a. www.tuik.gov.tr. 04.11.2016 Anonim, 2018. http://www.tuik.gov.tr. 22.08.2019

Azkan, N., 1999. Yemeklik Tane Baklagiller, Uludağ Üniversitesi, Ziraat Fakültesi Ders Notları; 40:107.
Babagil, G.E., 2011, Erzurm Ekolıjik Koşullarında Bazı Nohut (Cicer arietinum L.) Çeşitlerinin Verim ve Verim Özelliklerinin İncelenmesi, Anadolu Tarım Bilim Dergisi, 26(2). 122-127.

Babaoğlu, M., 2003. Nohut ve Tarımı (Cicer arietinum L.), Trakya Tarımsal Araştırma Enstitüsü Müdürlüğü., Edirne Blum, A. 1986.

Bakoğlu A., Memiş, A. 2002. Farklı Oranlarda Ekilen Adi Fiğ (Vicia sativa L.) ve Arpa (Hordeum vulgare L.) Karışımlarında Tohum Verimi ve Bazı Özelliklerin Belirlenmesi. Firat Üniversitesi Fen ve Mühendislik Bilimleri Dergisi, 14(1): 29-35.

Bakoğlu, A. ve Ayçiçek, M., 2005. Bingöl Ekolojik Koşullarında Bazı Nohut (Cicer arietinum L.) Çeşitlerinin Verim ve Verim Öğeleri Üzerine Bir Araştırma. Fırat Üniversitesi Fen ve Mühendislik Bilimleri Dergisi,17(1).107-113.

Bayrak, H., Keleş,R., İmriz, G., (2015) İleri Kademe Nohut Hatlarının ve Çeşitlerin Konya Ekolojisindeki Bazı Verim Karakterlerinin Belirlenmesi. Bahri Dăgdaş Bitkisel Araştırma Dergisi, 4(2): 32-37.

Beysarı, V., 2012. Bazı Nohut (Cicer arietinum L.) Çeşitlerinin Bingöl Koşullarındaki Verim ve Adaptasyon Koşullarının Belirlenmesi, Yüksek Lisans Tezi, Bingöl Üniversitesi Fen Bilimleri Enstitüsü

Biçer, B.T., Anlarsal, A. E., 2004. Bazı nohut (Cicer arietinum L.) köy çeşitlerinde bitkisel ve tarımsal özelliklerin belirlenmesi, Tarım Bilimleri Dergisi, Cilt 10(4).389-396

Bildirici, N., Çiftçi, V., Doğan, Y., 2007a. Van-Gevaş sulu koşullarında farklı sıra aralıklarının nohut (Cicer arietinum L.)' da verim ve bazı verim öğelerine etkisi. Türkiye VII. Tarla Bitkileri Kongresi, 25-27 Haziran, Erzurum.

Bildirici, N., Çiftçi, V., Doğan, Y., 2007b. Van-Gevaş sulu koşullarında DAP (Diamonyumfosfat) gübre dozlarının Canıtez-87 nohut (Cicer arietinum L.) çeşidinde verim ve bazı verim öğelerine etkisi. Türkiye VII. Tarla Bitkileri Kongresi, 25-27 Haziran, Erzurum, Türkiye.

Ceran, F., 2015. Farkl Zamanlarda Ekilen Nohut (Cicer arietinum L.) Çeşitlerinin Bazı Tarımsal Özelliklerinin Belirlenmesi, Yüksek Lisans Tezi, Selçuk Üniversitesi Fen Bilimleri Enstitüsü

Çiftçi, V., Doğan, Y., Togay, N., Karakuş. M., 2004. Türkiye’de Tescil Edilmiş Bazı Nohut (Cicer arietinum L.) Çeşitlerinin Van Ekolojik Koşullarında Verim Ve Verim Öğelerinin Belirlenmesi, Ç.Ü.Ziraat Fakültesi Dergisi, 19(2):105-110

Dinç, A., 2014. Türkiye'de Tescil Edilmiş Bazı Nohut (Cicer arietinum L.) Çeşitlerinin Van Koşullarında Verim ve Verim Öğelerinin Belirlenmesi, Yüksek Lisans Tezi, Yüzüncü Yıl Üniversitesi, Fen Bilimleri Enstitüsü

Doğan Y., 2014 Mardin Kızıltepe Ekolojik Koşullarında Kışlık Olarak Yetiştirilebilecek Nohut (Cicer arietinum L.) Çeşitlerin Belirlenmesi , Gaziosmanpaşa Üniversitesi Ziraat Fakültesi Dergisi, Cilt 31(1). 37-46

Düzgüneş, O., Kesici, T., Kavuncu, O., Gürbüz, F., 1987. Araştırma ve Deneme Metotları (İstatistik Metotları-II). Ankara Üniversitesi, Ziraat Fakültesi Yayınları: 1021:295

Engin, M. 1989 a. Çukurova Koşullarında Yüksek Verimli Nohut Çeşitlerinin Belirlenmesi Üzerine Bir Araştırma. Çukurova Üniversitesi Ziraat Fakültesi Dergisi, 4 (6):93103.

Engin, M. 1989 b. Çukurova Koşullarında Yüksek Verimli ve Makinalı Hasada Uygun Kışlık Nohut (Cicer arietinum L.) 
Çeşitlerinin Belirlenmesi Üzerine Bir Araştırma. Çukurova Üniversitesi Ziraat Fakültesi Dergisi, 4 (6):75-83.

Ercan, M.Y.İ., Uzun, S., Özaktan, H., 2019. Kayseri Ekolojik Koşullarında Farklı Ekim Zamanlarının Nohut (Cicer arietinum L.) Bitkisinde verim, verim unsurlar1 ve kalite üzerine etkileri. Avrupa Bilim ve Teknoloji Dergisi,(16):434440.

Erdemci, İ., 2012. Güneydoğu Anadolu Bölgesi Koşularında Farklı Nohut (Cicer arietinum L.) Genotiplerinin Yazlık Ve Kışlık Ekimlerinde Bazl Tarımsal ve Teknolojik Özeliklerinin Belirlenmesi, Doktora Tezi, Çukurova Üniversitesi, Fen Bilimleri Enstitüsü

Erdin, F., Kulaz, H., 2012. Van-Gevaş ekolojik koşulların da bazı nohut (Cicer arietinum L.) çeşitlerinin ikinci ürün olarak yetiştirilmesi. Türk Tarım ve Doğa Bilimleri Dergisi, 1, 910-914

Gan, Y. T., Siddique, K.H.M, MacLeod, W.J., Jayakumar, P., 2005. Managementoptions for minimizing the damage by ascochyta blight (Ascochyta rabiei) in chickpea (Cicer arietinum L.). Field Crops Res., 97; 121-134

Güngör, H., Dumlupınar, Z., (2018). Bazı nohut çeşit ve hatlarının verim ve verim unsurları bakımından değerlendirilmesi, Derim 35(2):194-200

Kaçar O., Göksu E., Azkan N., 2005. Bursa'da Kışlık Olarak Yetiştirilebilecek Nohut (Cicer arietinum L.) Hatlarının Belirlenmesi Uludă̆ Üniversitesi Ziraat Fakültesi Dergisi, 19 (2): 33-45.

Karaköy, T., 2008. Çukurova ve Orta Anadolu Bölgelerinde Toplanan Bazl Yerel Nohut (Cicer arietinum L.) Genotiplerin Verim Ve Verimle Ilgili Özelliklerin Belirlenmesi Üzerine Bir Araştırma, Doktora Tezi, Çukurova Üniversitesi Fen Bilimleri Enstitüsü

Karakan Kaya, F., 2014. Bazl Nohut (Cicer arietinum L.) Çeşitlerinin Elazı̆ Koşullarındaki Verim ve Adaptasyon Yeteneklerinin Belirlenmesi, Yüksek Lisans Tezi, Bingöl Üniversitesi Fen Bilimleri Enstitüsü

Karasu, A. 1993. Bazı Nohut Çeşitlerinin (Cicer arietinum L.) Agronomikve Teknolojik Karakterleri Üzerine Bir Araştırma. Doktora Tezi ,Uludağ Üniversitesi, Fen Bilimleri Enstitüsü, $122 \mathrm{~s}$.

Kaur, M., Singh, N., Sodhi, N. S., 2005. Physicochemical, cooking, textural and roasting characteristics of chickpea (Cicer arietinum L) cultivars. Journal of Food Engineering 69, 511-517.

Mart, D. ve A. E. Anlarsal. 2001. Çukurova Koşullarında Nohutta (Cicer arietinum L.) Bazı Önemli Özellikler Yönünden HatxÇevre İnteraksiyonları ve Uyum Yeteneklerinin Saptanması Üzerine BirAraștırma. Türkiye 4. Tarla Bitkileri Kongresi, 17-21 Eylül, Cilt I, Tahıllar ve Yemeklik Tane Baklagiller, s. 321-331.
Öztaş, E., Bucak, B., Al V., Kahraman, A., 2007. Farklı nohut (Cicer arietinum L.) çeşitlerinin harran ovası koşullarında kışa dayanıklılık, verim ve diğer özelliklerinin belirlenmesi, Harran Üniversitesi Ziraat Fakültesi Dergisi, 11(3/4):87-85

Patan, F., 2014. Tescilli Bazl Nohut (Cicer arietinum L.) Çeşitlerinin Erzurum Ekolojik Koşullarına Adaptasyonu, Yüksek Lisans Tezi, Atatürk Üniversitesi, Fen Bilimleri Enstitüsü

Saxena, M.C., 1990. Status of Chickpea in the Mediterranean Basin. CIHEAM Options Méditerranéennes-Série Séminairesn., 9; 17-24

Şehirali, S., 1988. Yemeklik Tane Baklagiller. Ankara Üniversitesi Ziraat Fakültesi, Ankara

Türk, Z., Koç, M., 2003. Diyarbakır koşullarında kuru ve sulu olarak yetiştirilen nohut (Cicer arietinum L.)'un verim ve verim unsurlarının belirlenmesi. Türkiye 5. Tarla Bitkileri Kongresi, 13-17 Ekim, Diyarbakır

Ulukan,H., 2012. Ankara Üniversitesi Ziraat Fakültesi Tarla Bitkileri Yaz Okulu Ders Notlart: 6, Ankara

Uzun, A., Özçelik, H., Yılmaz, S., 2012. Seçilmiş bazı nohut (Cicer arietinum L.) hatlarının agronomik vekalite özellikleri bakımından değerlendirilmesi, Akademik Ziraat Dergisi 1(1):29-36.

Üstün, A., 1994. Kuzey-Geçit bölgesinde nohut verimliliğini arttırma yolları. Tarım ve Köy Dergisi, Tarım ve Köy İşleri Bakanlığ

Yağmur, M., Engin, M., 2005. Farklı fosfor ve azot dozları ile bakteri aşılamanın nohut (Cicer arietinum L.)'un tane verimi ve bazı verim öğeleri ile ham protein oranı üzerine etkileri. Yüzüncü Yıl Üniversitesi, Ziraat Fakültesi, Tarım Bilimleri Dergisi, 15(2): 93-102.

Yalçın F, Mut Z, Erbas Kose OD (2018). Afyonkarahisar ve Yozgat Koşullarında Yüksek Verim Sağlayacak Uygun Nohut (Cicer arietinum L.) Çeşitlerinin Belirlenmesi. JAFAG, 35 (1), 46-59.

Yeşilgün, S., 2006. Çukurova Bölgesinde Bazı Kışlık Nohut (Cicer arietinum L.) Hat ve Çeşitlerinin Bitkisel Ve Tarımsal Özelliklerinin Saptanması,Yüksek Lisans Tezi, Çukurova Üniversitesi, Fen Bilimleri Enstitüsü

Yiğitoğlu, D., (2006). Kahramanmaraş Koşullarında Farklı Bitki Sılılklarının Klşlık ve Yazlık Ekilen Bazı Nohut Çeşitlerinde (Cicer arietinum L.) Verim ve Verim ile Ilgili Özelliklere Etkisi, Doktora Tezi, Çukurova Üniversitesi Fen Bilimleri Enstitüsü

Vural, H., Karasu, A., "Agronomical characteristics of several chickpea ecotypes (Cicer arietinum L.) grown in Turkey", Not. Bot. Hort. Agrobot. Cluj, Vol. : 35, Issue : 2, 2007.

Zeren, Y., Özcan, T., Işık, A., "Nohut hasat ve harman mekanizasyonu üzerine bir araştırma", Turkis Journal Of Agriculture and Forestry. 15: 215-238, 1991. 